\title{
Rancang Bangun Sistem Telemetri Pengukuran Ketinggian Gelombang Pasang Surut Air Laut secara Realtime Menggunakan Arduino Uno
}

\author{
Avinda Tria Vandhita, Dedy Hamdani, Desy Hanisa Putri \\ Program Studi Pendidikan Fisika, Jurusan Pendidikan MIPA \\ Fakultas Keguruan dan Ilmu Pendidikan \\ Universitas Bengkulu \\ E-mail: avindatriavandhita16@gmail.com
}

\begin{abstract}
ABSTRAK
Dalam penelitian ini telah dirancang dan dibangun sistem telemetri pengukuran ketinggian gelombang pasang surut air laut secara realtime menggunakan arduino uno. Metode yang digunakan dalam penelitian ini adalah Research and Development (R\&D). Prosedur pengembangan yang dilakukan pada penelitian ini meliputi planning (perencanaan), production (produksi) dan evaluation (evaluasi). Sistem telemetri ini bekerja melalui arduino uno yang mengambil data pengukuran melalui potensiometer dan memerintahkan modul nRF24L01+ untuk mengirimkan data pengukuran ke sistem penerima di darat. Data hasil pengukuran ini diterima oleh sistem penerima di darat untuk ditampilkan di PC/laptop. Hasil pengujian sistem telemetri ini menunjukkan bahwa sistem telemetri dapat bekerja dengan baik berdasarkan fungsinya dalam melaukan pengukuran, pengiriman dan penerimaan data hasil pengukuran ketinggian gelombang pasang surut. Dengan penelitian ini diharapkan dapat memberikan metode lain dalam memudahkan melakukan pengukuran ketinggian gelombang pasang surut air laut tanpa harus datang ke tempat pengukuran.
\end{abstract}

Kata Kunci: Arduino Uno, gelombang pasang surut, modul nRF24L01+ dan realtime

\begin{abstract}
In this research has been designed a telemetry system and measured the height of the tidal wave in realtime using Arduino Uno. The method used in this research is Research and Development ( $R$ \& $D)$. Procedures of development carried out in this study include planning production and evaluation. This telemetry system works through Arduino Uno which takes measurement data through a potentiometer and instructs the nRF24L01 + module to transmit measurement data to the receiving system on land. The measurement data is received by the receiver system on the ground to be displayed on the PC / laptop. The results of testing this telemetry system indicate that the telemetry system can work well based on its function in measuring, sending and receiving data from the measurement of tidal wave heights. This research is expected to provide other methods to facilitate measuring the height of the tidal wave without having to come to the measurement site.
\end{abstract}

Keywords: Arduio Uno, module nRF24L01+, Realtimeand tidal wave

\section{PENDAHULUAN}

Perkembangan zaman dan teknologi yang begitu pesat telah memberikan banyak kemudahan bagi manusia dalam berbagai bidang untuk memperoleh informasi. Namun, tidak demikian dalam bidang kelautan. Masih minimnya teknologi dalam bidang kelautan menjadi faktor penghambat memperoleh informasi mengenai ketinggian gelombang pasang surut air laut. Informasi mengenai pasang surut air laut tentunya sangat berguna bagi kegiatan manusia yang berkaitan dengan dunia kelautan seperti menangkap ikan, melintas dan berlabunya kapal di dermaga, dan berbagai kegiatan lainnya.

Kota Bengkulu sering kali mengalami perubahan cuaca yang tak menentu yang mengakibatkan Pelabuhan Perikanan Pulau Baai mengalami gelombang pasang surut yang cukup tinggi. Sehingga kondisi tersebut tidak memungkinkan untuk melakukan pemantauan dan pengukuran gelombang pasang surut secara langsung. Untuk mengatasi hal itu dapat dilakukan dengan mengembangkan suatu instrument pengukur ketinggian gelombang pasang surut yang memanfaatkan metode pemantauan dan pengukuran jarak jauh (telemetri). 
Telemetri adalah suatu proses pengendalian dan pengukuran data yang kemudian data hasil pengukuran dikirimkan ke tempat lain melalui media komunikasi jarak jauh dengan menggunakan kabel ataupun tanpa kabel (wireless).Sistem telemetri ini diharapkan dapat memberi kemudahan dalam pengukuran, pemantauan dan mengurangi hambatan untuk mendapatkan informasi. Secara umum sistem telemetri terbagi menjadi beberapa bagian pendukung seperti objek ukur, sensor, saluran transmisi, penerima dan tampilan/display [1].

Penelitian ini merancang sistem telemetri yang memungkinkan untuk melakukan pengukuran ketinggian gelombang pasang surut air laut. Sistem ini terdiri dari objek yang diukur, sensor, perangkat pengirim, perangkat penerima dan tampilan/display. Potensiometer digunakan untuk mengukur ketinggian gelombang pasang surut air laut.Modul nRF24L01+ digunakan sebagai perangkat pengirim di laut dan perangkat penerima di darat. Sehingga nantinya data hasil pengukuran yang diterima oleh perangkat penerima akanmenampilkan data hasil pengukuran secara realtime pada layar PC/laptop.Berdasarkan hasil pemikiran tersebut, maka diangkatlah penelitian yang berjudul: "Rancang

Bangun Sistem Telemetri Pengukuran Ketinggian Gelombang Pasang Surut Air Laut Secara Realtime Menggunakan Arduino Uno".

Adapun rumusan masalah pada penelitian ini yaitu; 1) Bagaimana merancang sistem telemetri pengukuran ketinggian gelombang pasang surut air laut secara realtime menggunakan Arduino Uno?; 2) Bagaimana membuat sistem telemetri pengukuran ketinggian gelombang pasang surut air laut secara realtime menggunakan Arduino Uno?

\section{METODE PENELITIAN}

Jenis penelitian yang dilakukan ini merupakan penelitian penemuan dan pengembangan (research and development). "Metode penelitian (R\&D) adalah metode penelitian yang digunakan untuk menghasilkan produk baru, menguji keefektifan produk yang sudah ada, serta mengembangkan dan menciptakan produk baru". Menurut Richey and Klein (2009) ada tiga langkah penelitian dan pengembangan, yaitu dimulai dengan tahap planning (perencanaan), kemudian production (produksi), dan terakhir evaluation (evaluasi) [2].

Tahap planning merupakan tahap perencanaan produk yang dibuat pada penelitian yang dilakukan. Pada tahap planning terdapat 2 langkah, yaitu analisis kebutuhan berupa studi lapangan dan studi literatur sehingga dapat diidentifikasi perangkat apa saja yang dibutuhkan serta rancangan produk yang diinginkan. Berdasarkan analisis kebutuhan tersebut, dihasilkan komponen-komponen perangkat keras (hardware) yang dgunakan diantaranya Arduino Uno, potensiometer. Modul nRF24L01+. Sedangkan perangkat lunak (software) yang digunakan pada penelitian ini yaitu perangkat lunak Arduino IDE dan Visual Basic 2010 Express. Selanjutnya pada langkah perancangan melakukan perancangan produk yang dibuat. Pada langkah perancangan terdapat 3 perancangan, yaitu:

1) Perancangan Perangkat Keras (Hardware)

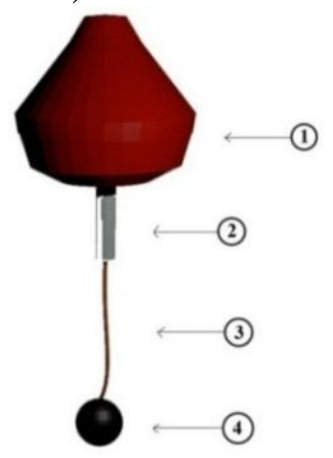

Gambar 1. Rancangan Pelampung

Perancangan perangkat keras ini berupa perancangan pelampung.Pelampung ini dimaksudkan sebagai tempat meletakkan komponen elektronik agar tidak terkena air laut.Berdasarkan Gambar 1 di 
atas, Pelampung ini terdiri dari empat bagian utama yaitu: 1) Pelampung berfungsi sebagai pelampung dan tempat dari sistem pelampung itu sendiri; 2) Tiang penyangga pelampungberfungsi sebagi penyangga pelampung agar tetap pada posisi tegak lurus; 3) Tali jangkar berfungsi untuk mengikat antara pelampung dan jangkar penambat; 4) Jangkar berfungsi sebagai jangkar penambat sistem pelampung, agarpelampungtetap pada posisinyadan tidak hanyut karena arus laut.

2) Perancangan Sistem Elektronik

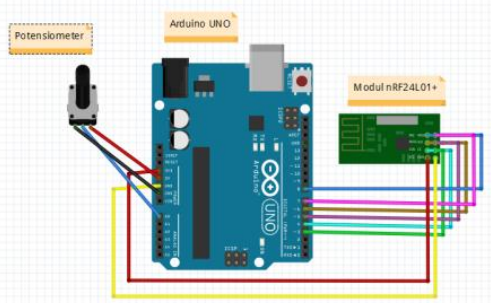

Gambar 2. Perancangan Sistem Pelampung

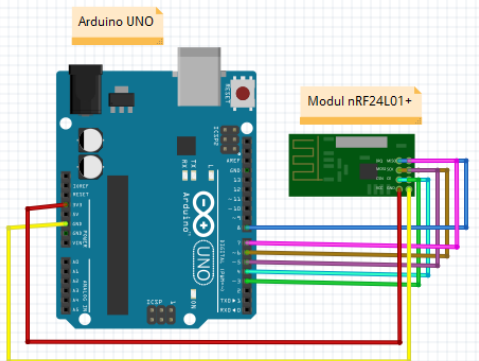

Gambar 3. Perancangan Sistem Penerima di Darat

Gambar 2dan Gambar 3di atasmerupakan gambar dari rancangan sistem elektronik produk yang dibuat. Komponen elektronik yang digunakan pada penelitian ini terdiri dari dua sistem yaitu sistem pelampung dan sistem penerima di darat

3) Perancangan Perangkat Lunak (Software)

Aplikasi yang digunakan dalam pembuatan rancangan perangkat lunak interface data hasil pengukuran ketinggian gelombang pasang surut air laut ini menggunakan Visual Basic 2010 Express. Gambar 4 menunjukkan rancangan interface data hasil pengukuran ketinggian gelombang pasang surut.

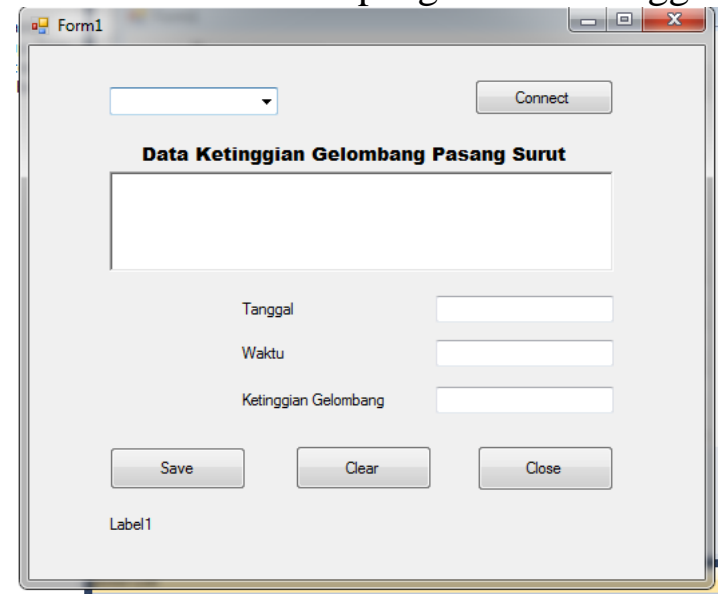

Gambar 4. Rancangan interface

Setelah melalui tahap perancangan, tahap selanjutnya adalah produksi.Tahap ini merupakan realisasi dari perancangan sistem pelampung dan sistem penerima di darat yang terintegrasi sebagai sistem telemetri pengukuran ketinggian gelombang pasang surut ai laut.

Tahapan terakhir pada penelitian ini adalah evaluasi.Evaluasi dilakukan berupa pengujian sistem telemetri pengukuran ketinggian gelombang pasang surut air laut di Pelabuhan Perikanan seperti yang 
ditunjukkan pada Gambar 5.Pengujian ini dilakukan sekaligus dengan pengambilan data.Data tersebut dianalisis dan diolah sehingga dapat diketahui waktu terjadinya pasang surut air laut.

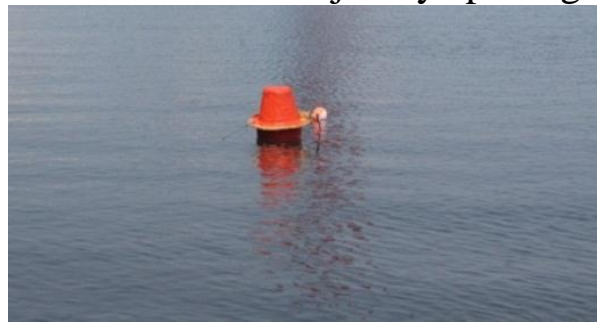

Gambar 5. Pengujian sistem telemetri di Pelabuhan Perikanan

\section{HASIL DAN PEMBAHASAN}

Pada penelitianRancang Bangun Sistem Telemetri Pengukuran Ketinggian Gelombang Pasang Surut Air LautSecara Realtime Menggunakan Arduino Unopembuatannya melalui 3 tahapan yang telah di jelaskan pada metode penelitian di atas.Tahapan tersebut di antaranya tahap perencanaan, produksi, dan evaluasi.

Pembuatan Rancang Bangun Sistem Telemetri Pengukuran Ketinggian Gelombang Pasang Surut Air LautSecara Realtimetelah melalui tahapan-tahapan yang sesuai dengan penelitian RND (Research And Development) secara berurutan, mulai dari tahapan perencananaan sampai tahapan evaluasi. Pada tahapan perencanaan, dilakukan kegiatan analisis kebutuhan meliputi studi lapangan dan studi literatur. Sehingga dapat diidentifikasi perangkat apa saja yang diperlukan serta rancangan produk yang diinginkan. Dari hasil rancangan ini yang akan dilanjutkan pada tahap produksi (production). Tahap produksi merupakan tahapan memproduksi produk yang disesuaikan dengan rancangan produk yang telah dibuat pada langkah perancangan di tahap perencanaan. Pada tahapan produksi terdapat 2 langkah, yaitu pembuatan sistem pelampung dan sistem penerima di darat.

Setelah melalui tahap perancangan, tahap selanjutnya adalah produksi. Tahap ini merupakan realisasi dari perancangan sistem pelampung dan sistem penerima di darat.

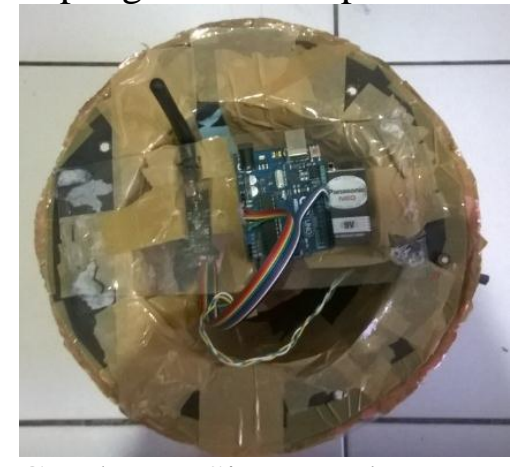

Gambar 6. Sistem pelampung

Gambar 6 memperlihatkan bahwa sistem pelampung terdiri dari pelampung dan komponenkomponen elektronik. Komponen-komponen elektronik ini terdiri atas Arduino Uno, potensiometer, modul nRF24L01+ dan catu daya 9V.

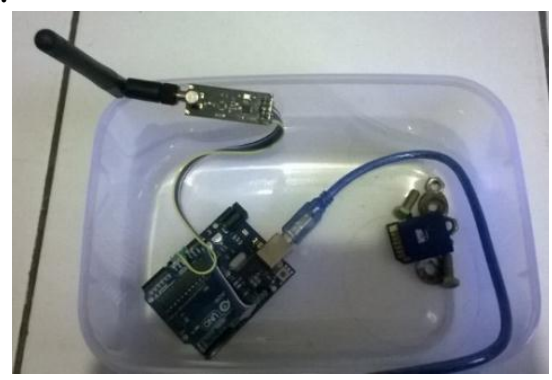

Gambar 7. Sistem penerima di darat 
Gambar 7menunjukkan bahwa sistem penerima di darat terdiri dari komponen-komponen elektronik seperti Arduino Uno, modul nRF24L01+. Dengan menghubungkan kedua sistem yaitu sistem pelampung dan sistem penerima di darat, maka diperoleh sistem telemetri pengukuran ketinggian gelombang pasang surut yang merupakan topik pada penelitian ini.

Tahap evaluasi dilakukan dengan menguji sistem telemetri secara keseluruhan di Pelabuhan Perikanan Pulau Baai selama dua hari. Data hasil pengukuran ketinggian gelombang yang telah masuk ke PC/laptop diolah kembali untuk mendapatkan nilai SWL (Still Water Level) yang digunakan sebagai titik acuan 0. SWL atau still water level merupakan tinggi muka air laut tenang tanpa dipengaruhi gelombang. Nilai SWL ini diperoleh dengan mencari rata-rata ketinggian gelombang pasang surut [3]. Setelah diperoleh nilai SWL, maka dapat diketahui pergerakan potensiometer di atas nilai 0 yang merupakan puncak gelombang dan pergerakan potensiometer di bawah nilai nol yang merupakan lembah gelombang.

Tabel 1. Data hasil pengukuran dengan nilai SWL

\begin{tabular}{|c|c|c|c|}
\hline \\
\hline Tanggal & Waktu & Ketinggian $(\mathrm{cm})$ & Amplitudo $(\mathrm{cm})$ \\
\hline $26 / 7 / 2018$ & 7:00:00 & 21.65 & -0.06 \\
\hline $26 / 7 / 2018$ & $7: 30: 00$ & 21.75 & 0.04 \\
\hline $26 / 7 / 2018$ & $8: 00: 00$ & 21.75 & 0.04 \\
\hline $26 / 7 / 2018$ & $8: 30: 00$ & 21.8 & 0.09 \\
\hline $26 / 7 / 2018$ & 9:00:00 & 21.98 & 0.27 \\
\hline $26 / 7 / 2018$ & $9: 30: 00$ & 22.2 & 0.49 \\
\hline $26 / 7 / 2018$ & 10:00:00 & 22.38 & 0.67 \\
\hline $26 / 7 / 2018$ & 10:30:00 & 22.5 & 0.79 \\
\hline $26 / 7 / 2018$ & 11:00:00 & 22.74 & 1.03 \\
\hline $26 / 7 / 2018$ & 11:30:00 & 22.96 & 1.25 \\
\hline $26 / 7 / 2018$ & 12:00:00 & 23.08 & 1.37 \\
\hline $26 / 7 / 2018$ & 12:30:00 & 22.86 & 1.15 \\
\hline $26 / 7 / 2018$ & 13:00:00 & 22.56 & 0.85 \\
\hline $26 / 7 / 2018$ & 13:30:00 & 22 & 0.29 \\
\hline $26 / 7 / 2018$ & 14:00:00 & 21.49 & -0.22 \\
\hline $26 / 7 / 2018$ & $14: 30: 00$ & 21.22 & -0.51 \\
\hline $26 / 7 / 2018$ & 15:00:00 & 20.79 & -0.92 \\
\hline $26 / 7 / 2018$ & $15: 30: 00$ & 20.5 & -1.21 \\
\hline 26/7/2018 & 16:00:00 & 20.39 & -1.32 \\
\hline $26 / 7 / 2018$ & $16: 30: 00$ & 20.5 & -1.21 \\
\hline $26 / 7 / 2018$ & 17:00:00 & 20.59 & -1.12 \\
\hline $26 / 7 / 2018$ & 17:30:00 & 20.63 & -1.08 \\
\hline $26 / 7 / 2018$ & 18:00:00 & 20.98 & -0.73 \\
\hline \multicolumn{3}{|c|}{ SWL (Still Water Level) } & 21,71 \\
\hline $27 / 7 / 2018$ & 7:00:00 & 21,93 & $-0,06$ \\
\hline $27 / 7 / 2018$ & $7: 30: 00$ & 21,95 & $-0,04$ \\
\hline $27 / 7 / 2018$ & 8:00:00 & 21,98 & $-0,01$ \\
\hline $27 / 7 / 2018$ & $8: 30: 00$ & 22 & 0,01 \\
\hline $27 / 7 / 2018$ & 9:00:00 & 22,12 & 0,13 \\
\hline $27 / 7 / 2018$ & 9:30:00 & 22,21 & 0,13 \\
\hline $27 / 7 / 2018$ & 10:00:00 & 22,32 & 0,33 \\
\hline
\end{tabular}




\begin{tabular}{|c|c|c|c|}
\hline Tanggal & Waktu & Ketinggian $(\mathrm{cm})$ & Amplitudo $(\mathrm{cm})$ \\
\hline $27 / 7 / 2018$ & $10: 30: 00$ & 22,48 & 0,49 \\
\hline $27 / 7 / 2018$ & $11: 00: 00$ & 22,56 & 0,57 \\
\hline $27 / 7 / 2018$ & $11: 30: 00$ & 22,88 & 0,89 \\
\hline $27 / 7 / 2018$ & $12: 00: 00$ & 23 & 1,01 \\
\hline $27 / 7 / 2018$ & $12: 30: 00$ & 22,94 & 0,95 \\
\hline $27 / 7 / 2018$ & $13: 00: 00$ & 22,5 & 0,51 \\
\hline $27 / 7 / 2018$ & $13: 30: 00$ & 21,7 & $-0,29$ \\
\hline $27 / 7 / 2018$ & $14: 00: 00$ & 21,7 & $-0,29$ \\
\hline $27 / 7 / 2018$ & $14: 30: 00$ & 21,59 & $-0,40$ \\
\hline $27 / 7 / 2018$ & $15: 00: 00$ & 21,4 & $-0,59$ \\
\hline $27 / 7 / 2018$ & $15: 30: 00$ & 21,4 & $-0,59$ \\
\hline $27 / 7 / 2018$ & $16: 00: 00$ & 21,29 & $-0,70$ \\
\hline $27 / 7 / 2018$ & $16: 30: 00$ & 21,3 & $-0,69$ \\
\hline $27 / 7 / 2018$ & $17: 00: 00$ & 21,4 & $-0,59$ \\
\hline $27 / 7 / 2018$ & $17: 30: 00$ & 21,52 & $-0,47$ \\
\hline $27 / 7 / 2018$ & $18: 00: 00$ & 21,65 & $-0,34$ \\
\hline \multicolumn{3}{|c|}{ SWL (Still Water Level) } & 21,99 \\
\hline
\end{tabular}

Hasil pengukuran ketinggian gelombang pasang surut air laut dapat dilihat pada Gambar 6 danGambar 7dan Gambar 8 memperlihatkan hasil pengukuran ketinggian gelombang pasang surut air laut pada tanggal 26 Juli 2018 dengan ketinggian puncak sebesar 1,37 cm di atas SWL pada pukul $12.00 \mathrm{WIB}$ dan kedalaman lembah sebesar 1,32 cm di bawah SWL pada pukul $16.00 \mathrm{WIB}$.

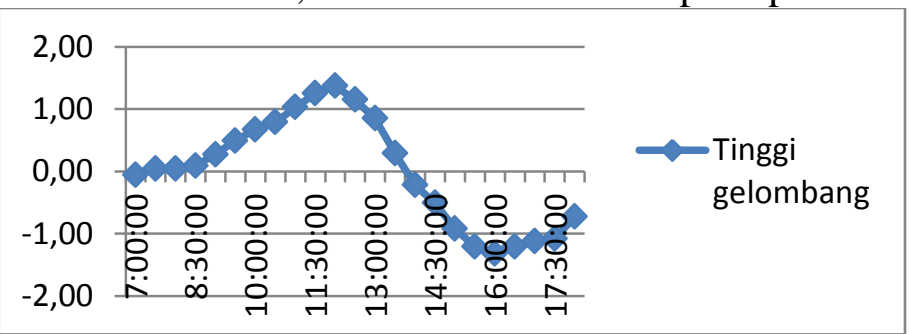

Gambar 8. Grafik hasil pengukuran pada tanggal 26 Juli 2018

Pada gambar 8memperlihatkan hasil pengukuran ketinggian gelombang pasang surut air laut pada tanggal 27 Juli 2018 dengan ketinggian puncak sebesar 1,01 cm di atas SWL pada pukul $12.00 \mathrm{WIB}$ dan kedalaman lembah sebesar $0,70 \mathrm{~cm}$ di bawah SWL pad pukul 16.00 WIB. Sehingga diketahui bahwa pada pukul 12.00 WIB terjadi pasang naik dan pada pukul 16.00 WIB terjadi pasang surut

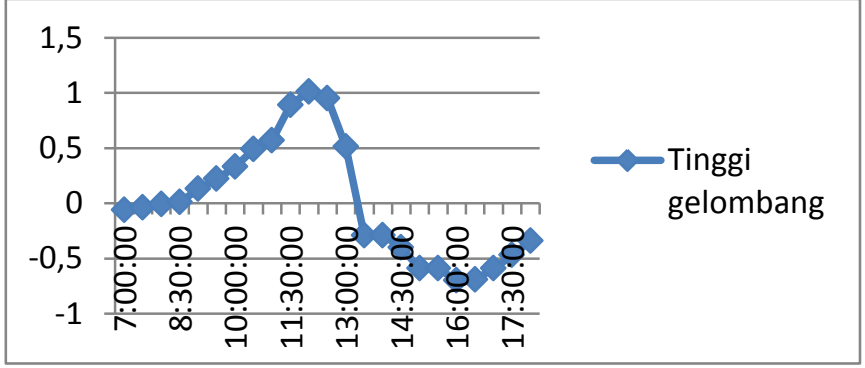

Gambar 9. Grafik hasil pengukuran pada tanggal 27 Juli 2018

Selanjutnya dilakukan perhitungan standar deviasi untuk mencari seberapa jauh nilai kesalahan pengukuran pada sistem telemetri pengukuran ketinggian gelombang pasang surut air laut.Terlebih dahulu dicari nilai rata data pengkuruan. Adapun nilai rata-rata data hasil pengukuran pada pada tanggal 26 Juli 2018 dari Tabel 1 sebagai berikut: 


$$
\bar{X}=21.71
$$

Tabel 2. Perhitungan data pengukuran pada tanggal 26 Juli 2018

\begin{tabular}{|l|c|c|c|}
\hline No. & $X$ & $(X-\bar{X})$ & $(X-\bar{X})^{2}$ \\
\hline 1. & 21,65 & $-0,06$ & 0,0036 \\
\hline 2. & 21,75 & 0,04 & 0,0016 \\
\hline 3. & 21,75 & 0,04 & 0,0016 \\
\hline 4. & 21,8 & 0,09 & 0,0081 \\
\hline 5. & 21,98 & 0,27 & 0,0729 \\
\hline 6. & 22,2 & 0,49 & 0,2401 \\
\hline 7. & 22,38 & 0,67 & 0,4489 \\
\hline 8. & 22,5 & 0,79 & 0,6241 \\
\hline 9. & 22,74 & 1,03 & 1,0609 \\
\hline 10. & 22,96 & 1,25 & 1,5625 \\
\hline 11. & 23,08 & 1,37 & 1,8769 \\
\hline 12. & 22,86 & 1,15 & 1,3225 \\
\hline 13. & 22,56 & 0,85 & 0,7225 \\
\hline 14 & 22 & 0,29 & 0,0841 \\
\hline 15. & 21,49 & $-0,22$ & 0,0484 \\
\hline 16. & 21,22 & $-0,51$ & 0,2601 \\
\hline 17. & 20,79 & $-0,92$ & 0,8464 \\
\hline 18. & 20,5 & $-1,21$ & 1,4641 \\
\hline 19. & 20,39 & $-1,32$ & 1,7424 \\
\hline 20. & 20,5 & $-1,21$ & 1,4641 \\
\hline 21. & 20,59 & $-1,12$ & 1,2544 \\
\hline 22. & 20,63 & $-1,08$ & 1,1664 \\
\hline 23. & 20,98 & $-0,73$ & 0,5329 \\
\hline & $n$ & & $X$ \\
\hline
\end{tabular}

Setelah diperoleh data pengukuran seperti yang ditunjukkan pada tabel Tabel,selanjutnya dicari nilai standar deviasinya dengan persamaan berikut:

$$
S=\sqrt{\frac{(X-\bar{X})^{2}}{n-1}}=\sqrt{\frac{16.805}{23-1}}=0.87
$$

dengan nilai maksimum $=23.08-=22.21 \mathrm{~cm}$ dan nilai minimum $=20,39-0,87=19.52 \mathrm{~cm}$.

Besarnya persentase nilai kesalahan dapat dihitung dengan menggunakan persamaan sebagai berikut:

$$
\text { error } \%=\frac{0,87}{22,21} \times 100 \%=3.92 \%
$$

Dari hasil pengolahan data tersebut dapat diketahui bahwa pada rancang bangun sistem telemetri pengukuran ketinggian gelombang pasang surut memiliki nilai persentase error sebesar $4.54 \%$ pada pengukuran tanggal 26 Juli 2018.

Nilai rata-rata data hasil pengukuran pada tanggal 27 Juli 2018 dari Tabel 2 adalah:

$$
\bar{X}=21.99
$$

Tabel 3. Data hasil pengukuran pada tanggal 27 Juli 2018

\begin{tabular}{|l|c|c|c|}
\hline No. & $X$ & $(X-\bar{X})$ & $(X-\bar{X})^{2}$ \\
\hline 1. & 21,93 & $-0,06$ & 0,0036 \\
\hline 2. & 21,95 & $-0,04$ & 0,0016 \\
\hline
\end{tabular}




\begin{tabular}{|l|c|c|c|}
\hline No. & $X$ & $(X-\bar{X})$ & $(X-\bar{X})^{2}$ \\
\hline 3. & 21,98 & $-0,01$ & 0,0001 \\
\hline 4. & 22 & 0,01 & 0,0001 \\
\hline 5. & 22,12 & 0,13 & 0,0169 \\
\hline 6. & 22,21 & 0,13 & 0,0484 \\
\hline 7. & 22,32 & 0,33 & 0,1089 \\
\hline 8. & 22,48 & 0,49 & 0,2401 \\
\hline 9. & 22,56 & 0,57 & 0,3249 \\
\hline 10. & 22,88 & 0,89 & 0,7921 \\
\hline 11. & 23 & 1,01 & 1,0201 \\
\hline 12. & 22,94 & 0,95 & 0,9025 \\
\hline 13. & 22,5 & 0,51 & 0,2601 \\
\hline 14. & 21,7 & $-0,29$ & 0,0841 \\
\hline 15. & 21,7 & $-0,29$ & 0,0841 \\
\hline 16. & 21,59 & $-0,40$ & 0,16 \\
\hline 17. & 21,4 & $-0,59$ & 0,3481 \\
\hline 18. & 21,4 & $-0,59$ & 0,3481 \\
\hline 19. & 21,29 & $-0,70$ & 0,49 \\
\hline 20. & 21,3 & $-0,69$ & 0,4761 \\
\hline 21. & 21,4 & $-0,59$ & 0,3481 \\
\hline 22. & 21,52 & $-0,47$ & 0,2209 \\
\hline 23. & 21,65 & $-0,34$ & 0,1156 \\
\hline & $n=23$ & & $\sum(X-\bar{X})^{2}=6,3945$ \\
\hline
\end{tabular}

Dicari nilai standar deviasi data hasil pengukuran dengan menggunakan persamaan sebagai berikut:

$$
S=\sqrt{\frac{(X-\bar{X})^{2}}{n-1}}=\sqrt{\frac{6.3945}{23-1}}=0.54
$$

dengan nilai maksimum $=23-0,54=22,46 \mathrm{~cm}$ dan nilai minimum $=21,3-0,54=20,76 \mathrm{~cm}$

Besarnya persentase nilai kesalahan dapat dihitung dengan menggunakan persamaan sebagai berikut:

$$
\text { error } \%=\frac{0,54}{22,46} \times 100 \%=2.40 \%
$$

Dari hasil pengolahan data tersebut dapat diketahui bahwa pada rancang bangun sistem telemetri pengukuran ketinggian gelombang pasang surut memiliki nilai persentase error sebesar 2,40\% pada pengukuran tanggal 27 Juli 2018.

Perbedaan besarnya persentase kesalahan pembacaan alat pada tanggal 26 dan 27 Juli 2018 disebabkan karena pengaruh kondisi alam sekitar Pelabuhan Perikanan Pulau Baai. Pada tanggal 26 Juli 2018 kondisi alam disekitar Pelabuhan Pulau Baai tidak terlalu berangin. Sementara pada hari kedua tanggal 27 Juli 2018 kondisi alam disektir Pelabuhan Perikanan Pulau Baai berangin sehingga menghasilkan persentase kesalahan pembacaan alat yang berbeda.

\section{SIMPULAN DAN SARAN}

\subsection{SIMPULAN}

Berdasarkan penelitian yang telah dilakukan dan pembahasan yang telah dijabarkan, diperoleh kesimpulan bahwasistem telemetri pengukuran ketinggian gelombang pasang surut air laut 
menggunakan Arduino Uno terdiri dari tiga perancangan yaitu perancangan pelampung, perancangan hardware dan perancangan software.Pada perancangan pelampung menggunakan aplikasi Blender, sehingga menghasilkan gambar pelampung tiga dimensi.Perancangan hardware terdiri dari dua bagian yaitu perancangan bagian sistem pelampung dan perancangan bagian penerima di darat.Perancangan hardware ini menggunakan aplikasi Fritzing. Sementara pada perancangan software interface untuk menampilkan data hasil pengukuran ketinggian gelombang pasang surut air laut menggunakan aplikasi Visual Basic 2010 Express.

Sistem telemetri pengukuran ketinggian gelombang pasang surut air laut menggunakan Arduino yang telah dibuat terdiri dari sistem pelampungdan sistem penerima di daratserta interface yang berfungsi sebagai penampil hasil pengukuran ketinggian gelombang pasang surut air laut di PC/laptop. Pada rangkaian transmitter terdiri atas Arduino Uno, potensiometer dan modul nRF24L01+.Rangkaian transimitter terletak di dalam pelampung, sehingga potensiometer dapat mengukur ketinggian gelombang pasang surut air laut sesuai dengan pergerakan pelampung.Rangkaian sistem penerema di darat, terdiri atas komponen-komponen elektronik yaitu Arduino Uno dan modul nRF24L01+. Rangkaian sistem penerima di darat ini berfungsi sebagai penerima data hasil pengukuran ketinggian gelombang pasang surut yang kemudian ditampilkan melalui interface yang telah dibangun dengan aplikasi Visual Basic 2010 Express. Sistem telemetri pengukuran ketinggian gelombang pasang surut air laut yang telah dibuat mampu melakukan pengukuran ketinggian gelombang pasang surut air laut dengan baik sesuai dengan fungsinya.

\subsection{SARAN}

Dalam pengembangan alat ini lebih lanjut, saran yang diberikan adalah sumber tegangan masukkan dapat ditambahkan solar cell agar dapat melakukan pengisian baterai tanpa harus mengganti baterai.Serta dalam penyimpanan data hasil pengukuran kedepannya diharapkan dapat langsung tersimpan ke Microsoft Excel.

\section{UCAPAN TERIMA KASIH}

Dengan terselesaikannya penelitian ini, penulis mengucapkan terimakasih yang sedalam-dalamnya kepada bapak Dedy Hamdani, M.Si selaku pembimbing utama dan ibu Desy Hanisa Putri, M.Si selaku pembimbing pendamping.

\section{DAFTAR PUSTAKA}

[1] Rahmadiansyah, A. (2017). Perancangan Sistem Telemetri Untuk Mengukur Intensitas Cahaya Berbasis Sensor Light Dependent Resistor Dan Arduino Uno. JEEE-U, 16.

[2] Sugiyono. (2017). Metode Penelitian dan Pengembangan (Research and Development). Bandung: Alfabeta.

[3] Wijaya, A. D., Mudin, Y., \& Farhansah, D. (2014). Rancang Bangun Alat Ukur Gelombang Pasang Surut Jarak Jauh dengan Memanfaatkan Short Message Services (SMS). Gravitasi, 7. 